Received $\quad 30.08 .2018$

Reviewed 23.10.2018

Accepted 29.11.2018

A - study design

B - data collection

C - statistical analysis

D - data interpretation

E - manuscript preparation

$\mathbf{F}$ - literature search

\title{
Private for-profit rural water supply in Nigeria: Policy constraints and options for improved performance
}

\author{
Michael Chukwuma OBETA ${ }^{\mathrm{ABCDEF} \otimes}$
}

orcid.org/0000-0001-5380-1379; University of Nigeria, Nsukka, Hydrology and Water Resources Unit, 410101, Nsukka, Nigeria; e-mail: michael.obeta@unn.edu.ng

For citation: Obeta M.Ch. 2019. Private for-profit rural water supply in Nigeria: Policy constraints and options for improved performance. Journal of Water and Land Development. No. 41 (IV-VI) p. 101-110. DOI: 10.2478/jwld-2019-0033.

\begin{abstract}
Water scarcity is a major and growing problem in Nigerian rural areas, leading to the emergence of private for-profit water services providers (PPWSPs). This paper characterizes the landscape of PPWSPs in Nigerian rural communities using information collected from field observations, in-depth interviews, questionnaire surveys, and from published water resources literature. The data collected were analysed through the use of descriptive statistical tools. The results revealed the characteristics, categories, contributions and concerns of water users regarding water supplies by PPWSPs. Responses show that PPWSPs are helping to engender development, guarantee end-users with access to sufficient and reliable supplies and reduce water shortages in the study communities. Sixty four percent of sampled households depend on PPWSPs for their water requirements. Many PPWSPs operate outside the purview of government regulations and have differentiated service modes and prizes to gain wider acceptability. Despite the progress made by PPWSPs, however, the strategy can neither guarantee universal access nor the supply of safe drinking water. Significant barriers to the operations of PPWSPs, how to close the policy-gaps that constrain services delivery by PPWSPs and improve performances through setting of standards and regulatory reforms are discussed.
\end{abstract}

Key words: improved performance, Nigeria, policy constraints, private water supplies, public water schemes, rural communities

\section{INTRODUCTION}

Private for-profit water services providers (PPWSPs) refer to individuals and/or small and micro-enterprises that generate, treat, and distribute water to households as commercial or business undertakings [ADELEYE et al. 2014]. PPWSPs are not formally charged by governments with the responsibility of providing water supply services but voluntarily invest in water infrastructure and run them like business [FOSTO et al. 2007]. Staring from the early 2000s, this new approach to public water supply in Nigeria has grown phenomenally, due largely to the underperformance of public water schemes and the assumption that private water suppliers are more flexible, more reliable and that competition between and among them would make public services more efficient and sustainable [AKPOR, MUCHIE
2011]. PPWSPs are widespread and are important feature of the economy of many countries in the world [HUSSMANNS 2004; LO STORTO et al. 2013] but literature which broadly investigates the landscape of their operations are generally lacking.

The underperformance and unsustainable water services delivery in Nigeria is well known [NWANKWOALA 2011; OMOLE 2015]. In most Nigerian rural communities, rural water supply schemes (RWSSs) have collapsed [AYOADE, OYEBANDE 1983] and except for a few areas, most rural dwellers face serious and persistent challenges in meeting their water needs. The water need of the rural population has been on the increase due to increases in the population and consumption rates [WHO, UNICEF 2012]; about 90 million people lack access to safe drinking water in Nigeria [EZENWAJI et al. 2016]. Poor access to house- 
hold water in rural communities in Nigeria is inextricably linked to poor and unsustainable service delivery [WHO, UNICEF 2015]. Service providers face many operational challenges such as poor service coverage, maintenance backlogs, endless problems with service provisions and frequent system failures; as a result this, many people lack access to safe drinking water [EZENWAJI et al. 2016]. In fact, OMOLE [2015] reported that in Nigeria, water supplies are not only inadequate but dwindling while EZENWAJI et al. [2016] added that most people in the rural areas still depend on unimproved drinking water sources for their water needs.

Although Nigeria has abundant surface and groundwater resources [ABAJE et al. 2009; FANIRAN 1992], many of the country's surface water bodies are polluted [OFOZIE 2003; PAVELIC et al. 2012]. The big rivers receive huge quantities of untreated effluents and solid wastes which contain substances that are not only harmful to humans but also to aquatic biota [BABIC et al. 2014; OLALEYE 2010]. In spite of the enormous environmental and public-health risks involved in using these polluted streams [METWALKY et al. 2006], many people, especially in rural communities have no option than to use them for human relatedpurposes, including drinking and cooking [OYEGUN 2011].

The poor public water services delivery in Nigeria and the 1999/2000 policy reforms which brought in public and private partnership in the water supply sector [ADELEYE et al. 2004], led to the emergence of PPWSPs. Currently, PPWSPs are actively involved in rural water supplies in all the 36 sates of Nigeria [OFOEZIE 2003; OKEJE 1989]. They develop, operate and manage local water schemes, especially in areas, where public water infrastructure is usually lacking [AKPOMUNJE 2010]. Although PPWSPs have been part of the rural economy of Nigeria for decades [NWANKWOALA 2011], studies which offer broad and detailed insights on their characteristics and contributions are generally lacking. Previous workers on the patterns and problems of rural water supply in Nigeria have not considered the landscape of PPWSPs (their contributions, strengths, constraints) and the policy environment under which they operate. They have looked at the subject mostly from the point of view of institutional strengthening of government water supply agencies [AKPOMUNJE 2010; BAGUMA et al. 2013; OMOLE et al. 2015]. For instance, AKPOMUNJE [2010] investigated the effectiveness of 'self-help' as a strategy for improving access to rural water supplies in Nigeria without going into the contributions and challenges facing private water suppliers. Besides, the data used in the study were very general and not specific to the rural community levels. The lack of relevant information on private approach to household water supply in Nigeria constrain effective decision on the type and nature of interventions required to promote sustainable delivery of water, especially in rural areas .

Providing relevant information on the landscape of private water services provision in Nigeria is a step forward in attempt to establish the right policy environment under which PPWSPs can operate as well as to promote sustainable rural water services delivery in Nigeria. This research seeks to provide relevant information on this vital issue in order to enhance our understanding of the prevailing situations and, in addition, may provide valuable insights on the type and nature of policies required to boost performance by the informal sector. The unsustainable nature of water services delivery in Nigeria is a major challenge which needs to be overcome if the rural economy is to be transformed. Achieving this requires extensive research in order to select policies and strategies that are informed by clear scientific insight . This study, in our view, will contribute in achieving this goal by suggesting how to close the policy-gaps that constrain the performance of PPWSPs in Nigeria.

\section{THEORETICAL LITERATURE REVIEW}

The institutional arrangements for rural water supply in Nigeria are summarized in Figure 1. As shown in Figure 1, rural water services delivery in Nigeria is on the concurrent legislative list according to the 1990 constitution of the Federal Republic of Nigeria. This means that each tier of government (local, state and federal) has legal powers to develop, treat and distribute both surface and ground water to users as well as to construct and maintain water supply infrastructural facilities; and that water services delivery is decentralized to the local level so that the private sector can build operate and maintain water supply infrastructure.

Presently, the under listed service providers are involved in rural water services delivery in Nigeria.

1) Federal Ministry of Water Resources: This federal government agency is the principal institution that plays both the central and supportive roles in water resources development in Nigeria. This agency is responsible for the formulation and implementation of policies, legislations, regulations and programmes that guide water supply services at the national level [ADEROGBA 2005]. However, the agency has no direct involvement in rural water services delivery other than in providing logistic support, funding specific (rehabilitation) initiatives and providing level playing fields to all stakeholders in the water sector [ADELEYE et al. 2014; ADEOYE et al. 2013].

2) The states water boards/corporations: these states agencies have the overall responsibilities for rural water services delivery in their respective areas of jurisdictions [ADELEYE et al. 2014]. They plan, coordinate, develop, operate, maintain and rehabilitate basic rural water infrastructure as well as license and register private water services providers and water user associations.

3) Local government authorities: local government authorities oversee the implementation of water supply development activities and water management within their boundaries [NZEADIBE, AJAERO 2010]. They act as regulators and service providers and have a role in fund raising to facilitate the provision of locally sustainable water supply facilities within their boundaries.

4) Non-governmental organizations (NGOs). Many NGOs as well as bilateral and multilateral organizations have invested in the development and rehabilitation of rural water infrastructure in Nigeria [ADEKAYI et al. 1991]. Prominent examples include the World Bank, WHO 


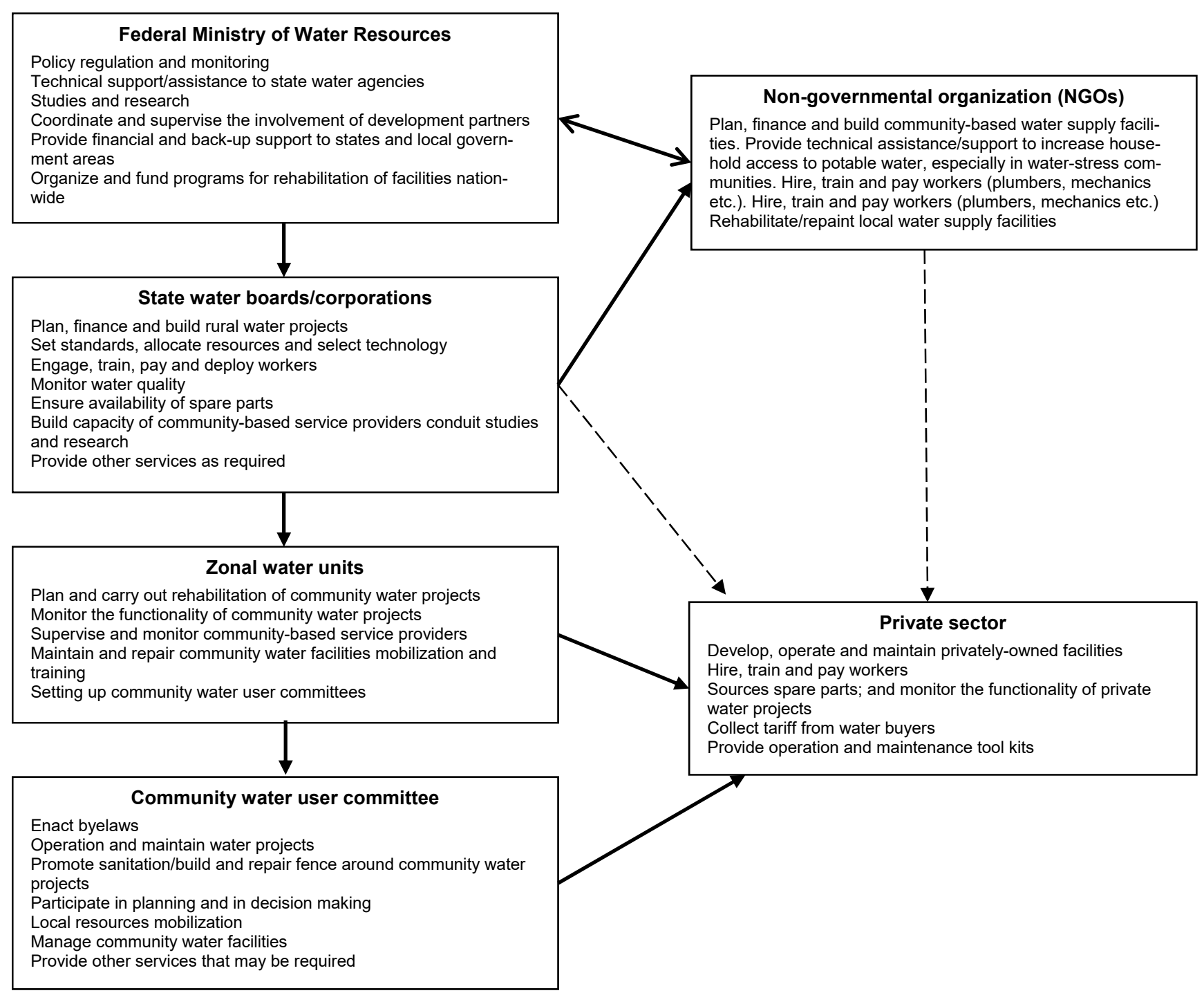

Fig. 1. Institutional framework for rural water supply in Nigeria; arrows show interaction between and among units; source: Federal Ministry of Water Resources [2016]

and UNICEF. These NGOs are involved in the construction of rural water supply infrastructure, distribution of new technologies within existing systems, and the rehabilitation of dysfunctional water infrastructure.

5) The private sector. The private sector plays active role in developing and managing private water infrastructure in Nigeria. A variety of private-sector initiatives powered by individuals, communities, firms and community based-organizations (CBOs) are now involved in public water supplies in Nigeria [CHITONYE 2011].

However, in spite of the involvement of the above agencies, the issue of water crisis and shortages in rural communities in Nigeria remain critical [OMOLE et al. 2015]. Water users face serious and persistent challenges in meeting their water needs [ADELEYE et al. 2014]. The factors which occasion the massive failures in the water systems have been discussed in details by OFOEZIE [2003], UlOCHA [2005], GBADEGESIN and OlORUNDEMI [2007], ABAJE et al. [2009] and OMOLE et al. [2015]. The inadequacies of public water supply services delivery, led to the emergence of PPWSPs which have become ubiquitous in Nigerian rural communities. Currently, there is limited literature on PPWSPs, not only in Nigeria but in both the developed and other developing countries [LO SORTO 2013]. The few available ones are predominantly made up of opinion pieces that are not truly academic or policy studies, hence the need for this study

\section{STUDY AREA}

Nigeria occupies an area of $923,769 \mathrm{~km}^{2}$ and consists of 36 federating states. The country lies between $4^{\circ} \mathrm{N}$ and $14^{\circ} \mathrm{N}$ of the equator (see Fig. 2) and shares border with Cameroon in the East, Chad in the North-East, Niger in the North and Benin in the South. Nigeria is ethnically diverse, with about 400 cultural groups speaking over 45 different languages [ADEKALU et al. 2014]. Currently the country has a population of more than 170 million people; the southern states are fairly well populated owing to their climate which is favourable to agricultural production [EZENWAJI et al. 2016]. Much of the northern states, being largely arid are sparsely populated; the Sahel region is almost uninhabited [AwOPEGBA 2001]. 


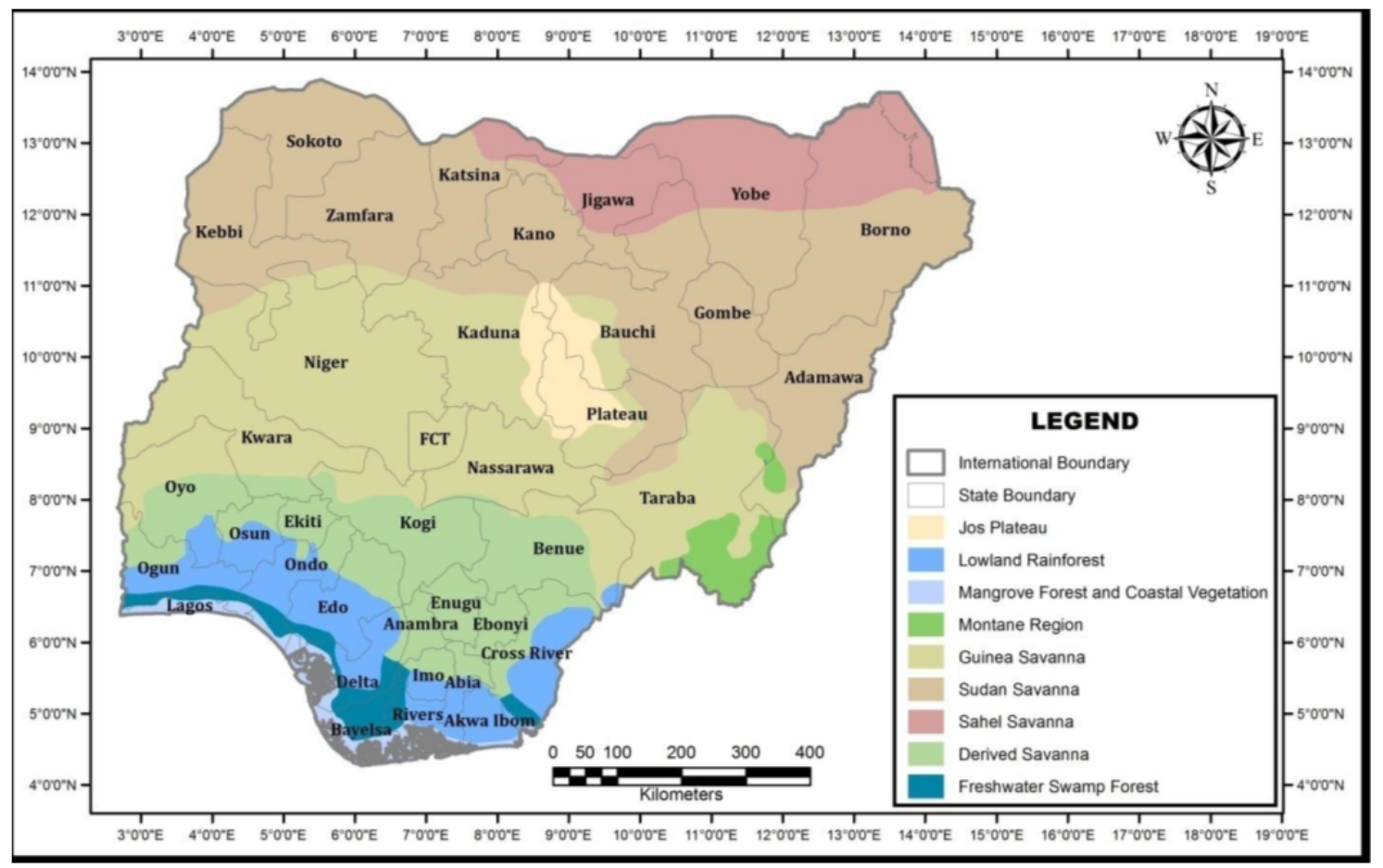

Fig. 2. Location and federating state in Nigeria; source: GIS Unit, Department of Geography University of Nigeria, Nsukka

The climate of the Nigeria is tropical, with high temperatures and relative high humidity as well as marked wet and dry seasons, though there are variations between regions [ALI 2012]. Rain falls unevenly over the country [AMINU 2000]. An interesting feature of the rainfall patterns in Nigeria is its variability, with coefficient of variation for mean monthly rainfall usually exceeding 35\% along the Gulf of Guinea. This pattern together with the seasonal variation of water availability make the direct collection and use of rain water more pronounced in the rainy season [AWUNH et al. 2009]. Rain fall is harvested widely and used for domestic purposes all over the country; with some hamlets, especially in southern states, depending almost on the harvested precipitation throughout the year for their water needs. The states that make up Nigeria are a mix of resource rich and resource poor, but are generally confronted with varying degrees of inadequate availability of freshwater resources [WAZIRI 2009].

\section{METHODS}

The characteristics and sources of data used in this study summarized below.

> Data on private water supplies, including information on the characteristics of private for-profit water services providers (PPWSPs), regularity of provision, sorts and types of PPWSPs, constraints to service provisions, contributions of PPWSPs characteristics of PPWSPs water infrastructure were obtained through indepth interviews with PPWSPs, household heads, community leaders and through questionnaire administration.

$>$ Data on the pros and cons of private water services delivery were obtained through three focus group discussions (FGD). In each of the FGD, nine participants, comprising, the zonal water engineer, three PPWSPS, three officials of community water supply committees and two women leaders were involved.

$>$ Secondary data were obtained from published documents: journals, books, government gazettes, project reports, mission reports and the internet.

$>$ Data on the contemporary public water supply situations in the area were collected from service providers, staff of national and state water supply agencies, community leaders as well as from the states' water boards/corporations the area.

Data collection took place in the six geo-political zones in Nigeria between October 2016 and March 2017; six states (Fig. 3) were randomly selected, one each from the six geo-political zones and used for the study. From the states one Local Government Area (LGA) was also drawn randomly for use in the study. Within the local government areas (LGAs) five rural communities were purposefully selected for sampling. A total of 30 rural communities were sampled. Only communities that are accessible have both public water schemes and PPWSPs were selected for the study. The names of the sampled communities and the numbers of households in the communities, in each of the sampled state are shown in Table 1.

Initial information on sampled PPWSPs was obtained through the assistance of household heads who gave the names and locations of PPWSPs from where they access household water. Four accessible and willing (i.e disposed to answer questions) PPWSPs in each community were observed and investigated. Interviews were conducted on 120 PPWSPs spread across 30 rural communities in the study area.

Also a total of 450 copies of questionnaires (at 15 per a community) were administered on household heads in the sampled 30 communities. The copies of the question- 


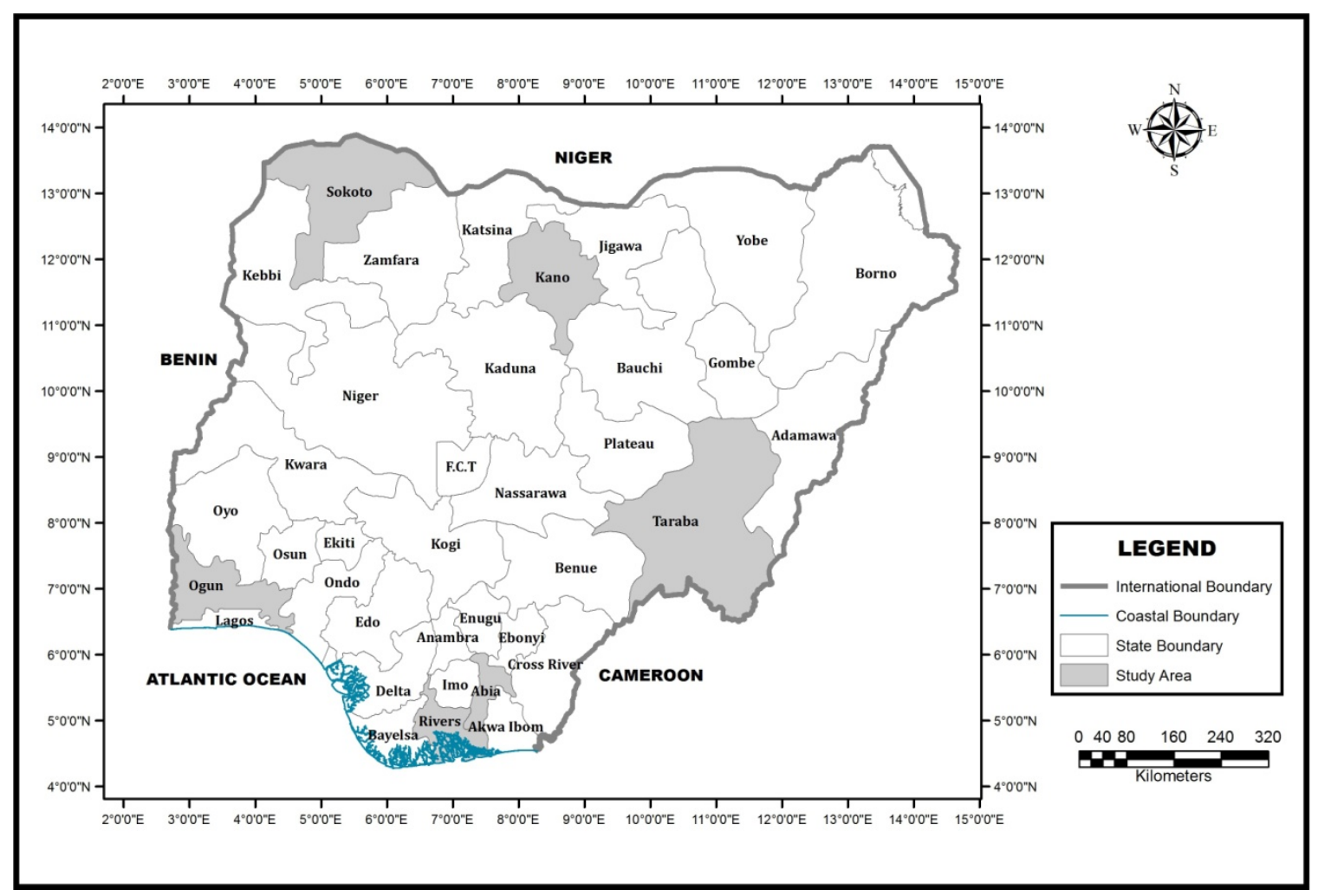

Fig. 3. Sampled states in Nigeria; source: GIS Unit, University of Nigeria, Nsukka

Table 1. Characterization of sampled states

\begin{tabular}{|c|c|c|c|c|c|c|c|}
\hline $\begin{array}{l}\text { Geo political zone/ } \\
\text { State }\end{array}$ & Sampled communities & $\begin{array}{l}2016 \text { projected } \\
\text { population }^{1)}\end{array}$ & $\begin{array}{l}\text { Land area } \\
\qquad\left(\mathrm{km}^{2}\right)\end{array}$ & $\begin{array}{c}\text { Density } \\
\text { (persons per } \\
\mathrm{km}^{2} \text { ) }\end{array}$ & $\begin{array}{c}\text { Rural/ } \\
\text { urban ratio }\end{array}$ & $\begin{array}{c}\text { Estimated } \\
\text { No. of } \\
\text { households }\end{array}$ & $\begin{array}{l}\text { Available/leading local } \\
\text { sources }\end{array}$ \\
\hline $\begin{array}{l}\text { South South Zone/ } \\
\text { Rivers }\end{array}$ & $\begin{array}{l}\text { Eziro Omoku, Obirikom } \\
\text { Ebocha, Akabuka }\end{array}$ & $5,185,400$ & 11,225 & 462 & $31 / 69$ & 3,449 & $\begin{array}{l}\text { streams, lakes, wells, rivers, } \\
\text { boreholes, vendors }\end{array}$ \\
\hline $\begin{array}{l}\text { North Centra Zone/ } \\
\text { Kano }\end{array}$ & $\begin{array}{l}\text { Tinja Ganbe, Bako, } \\
\text { Tashi, Rafi }\end{array}$ & $9,013,534$ & 17,011 & 241 & $30 / 70$ & 2,889 & $\begin{array}{l}\text { streams, rainwater, wells, } \\
\text { boreholes, vendors }\end{array}$ \\
\hline $\begin{array}{l}\text { South West Zone/ } \\
\text { Ogun }\end{array}$ & $\begin{array}{l}\text { Ayore, Ose, Ifon, Ikare, } \\
\text { Ijora }\end{array}$ & $3,728,098$ & 16,720 & 223 & $66 / 34$ & 3,314 & $\begin{array}{l}\text { streams, lakes, wells, rivers, } \\
\text { boreholes, vendors }\end{array}$ \\
\hline $\begin{array}{l}\text { South East Zone/ } \\
\text { Abia }\end{array}$ & $\begin{array}{l}\text { Uruagu, Uburu, Ngwa, } \\
\text { Udim, Oboro }\end{array}$ & $2,838,999$ & 4,877 & 554 & $70 / 50$ & 4,322 & $\begin{array}{l}\text { streams, lakes, wells, rivers, } \\
\text { boreholes, vendors, ponds }\end{array}$ \\
\hline $\begin{array}{l}\text { North East Zone/ } \\
\text { Taraba }\end{array}$ & $\begin{array}{l}\text { Wukari, Ginda Diwaya, } \\
\text { Fini, Kadi }\end{array}$ & $2,300,736$ & 54,473 & 42 & $24 / 76$ & 1,573 & $\begin{array}{l}\text { streams, lakes, wells, rivers, } \\
\text { boreholes }\end{array}$ \\
\hline $\begin{array}{l}\text { North West Zone/ } \\
\text { Sokoto }\end{array}$ & $\begin{array}{l}\text { Alami, Gudu Dinya, } \\
\text { Yadi, Mako }\end{array}$ & $3,696,999$ & 25,973 & 142 & $28 / 72$ & 1,374 & $\begin{array}{l}\text { streams, lakes, wells, rivers, } \\
\text { boreholes, vendors }\end{array}$ \\
\hline
\end{tabular}

Explanations: leading sources are highlighted.

Source: own elaboration and ${ }^{1)}$ NPC [2006]; ${ }^{2)}$ OMOLE, ISIORBO [2011].

naire were administered by two trained research assistants, who were indigenes of the states under study and post graduate students of the Department of Geography, University of Nigeria, Nsukka. Research assistants spent one day in each community to complete all data collection activities.

Descriptive statistical techniques (totals mean, percentages etc.) were used to interpret the results.

\section{RESULTS AND DISCUSSION}

\section{CHARACTERISTICS OF SAMPLED PPWSPS}

Findings revealed that PPWSPs have become ubiquitous in the sampled communities. They are helping to en- sure that there is sufficient water, in quantitative terms, to support the water needs of the users, especially as all the sampled communities, have (endless) problems with public water service provision. Two categories of private water services providers were observed. These are the private-for profit and private-for non-profit water service providers. The later consist mostly of individuals who wish to ameliorate the suffering of people in water stressed areas. Two categories of PPWSPs were also observed. These are the big-time and the small-scale PPWSPs. The big-time PPWSPs consist mostly of private borehole operators, water companies and dealers who use vehicles to abstract and distribute water. They are registered by states water agencies and are involved in the extraction, collection, distribution and management of water facilities, especially where 
public water infrastructure is usually lacking while the small-scale PPWSPs are more widespread and operate outside the purview of government regulations.

Observed PPWSPs were, indeed, an important feature of the economy of the sampled communities. They have devised various means of attracting and retaining customers; such as by creating various categories and sorts of PPWSPs in the study area. The categories range from individuals who sell water to end-users using bicycles, barrow, carts, and motorbikes, through those who sell from steel/ plastic/concrete tanks to the big-time dealers who use vehicles and/or develop perennial water supply sources such as deep wells, private boreholes, or distribute through piped water networks. A second strategy is to locate at busy centres, very close to the users and focusing mostly on those infrastructures that are relatively cheap to construct/purchase. Evidence shows that they deliver satisfactory levels of sustainability, however, they lack organized administrative/wage structure; workers are hired on casual basis and most projects are manned by their owners, who, generally lack engineering skills to maintain the water infrastructure.

\section{CONTRIBUTIONS OF PPWSPS TO THE PEOPLE'S WATER NEEDS}

Evidences from the field show that PPWSPS play active role in helping end users meet their water needs. Responses indicate that PPWSPS offer water users with quantity, accessibility, and reliable water supplies. Water users have easy access to water supplies; the water supply source is usually very close to users and water can also be delivered to users even at the point of use-homes or shops. Findings revealed that users are pleased with the availability and reliability of service delivery as well as with the prompt repairs of system faults by PPWSPS. Many households were found to depend primarily on PPWSPs. Figure 4 provides summary information on the level of dependence of sampled users on PPWSPS as shown in Figure 4, private water suppliers are the dominant service providers in four out of the six sampled states. The percentages of households that depend primarily on PPWSPS ranged from

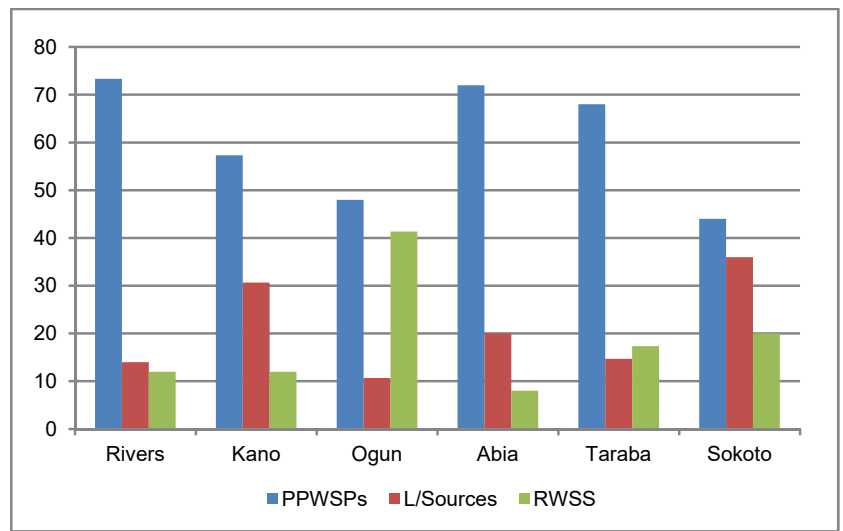

Fig. 4. Pattern of dependence on available sources in the study area; PPWSPs = private for-profit water services providers, $\mathrm{L} /$ Sources $=$ other local sources, $\mathrm{RWSS}=$ rural water supply scheme; source: own study
702.0\% (Abia), through 73.3\% (Rivers), 57.3\% (Kano), $68.0 \%$ (Taraba), $48.0 \%$ (Ogun) to $44.0 \%$ (Sokoto). Cumulatively, $60.4 \%$ of sampled households depend primarily on PPWSPs.

Responses, however, show that this approach has weaknesses which included the supply of water of doubtful quality and that privately supplied water is not affordable to all users. In spite of these weaknesses of private water supplies, findings indicate the approach has advantages. Responses show that PPWSPs are not just critical for sustainable rural water services delivery but are also the foundations for reducing mass poverty and for transforming rural economy; in some communities there are practically no alternative sources. PPWSPs also disciplines water users - to use no more than they can afford (this is very important in Nigeria where, according to LONGE et al. [2009], a strong culture for non-payment of water bills exist) and by extension reduces the overuse or wastage of water. Service delivery by PPWSPs offer strong control over consumption; reduces inefficiencies in resources management and enhances cost recovery.

\section{POLICY-GAPS CONSTRAINING THE OPERATIONS OF PPWSPS IN THE STUDY AREA}

Water policy provides guidance on the roles and responsibilities of all stakeholders involved in rural water project implementation, from communities to central bodies. Evidences from the sampled communities reveal that several policy-gaps constrain services delivery by PPWSPs in Nigeria. The most critical include:

- Non-provision of technical assistance to PPWSPs. Findings show that the 2000 National Water Acts of Nigeria did not mandate any agency to provide PPWSPs with assistance on technical issues relating to site selection, choice of technology, water project design, structure, construction, operation and maintenance of private water infrastructure. Water users opined that this limits the capacity of private service providers to provide quality services since most of the investors lack the essential engineering skills and competencies needed to drive water service provision. Judging from evidences received in the field, it is obvious that some PPWSPs lack the required technical knowledge and skills to operate and maintain water supply facilities or participate in their monitoring and evaluation. Worse still, there are no training undertaken to equip them for the roles they now play as managers of rural water supply systems. This undermines their ability to contribute to repairs and preventive maintenance.

- Non-protection of users interest. This study further sought information on the mechanisms put in place to safeguard the interest of water users served by private water companies and vendors and found that governments, in the sampled states, have not set-up agencies to address some fraudulent and sharp practices associated with business operations in Nigeria, one of which is extortion, especially in areas where alternative sources do not exist. Users too have no consumers unions to protect their interests. In fact, one of our respondents opined 
that government has no business with privately supplied water in his community.

- Non-regulation of the operations of PPWSPs. Responses show that PPWSPs are neither monitored nor regulated by National/State agencies. Under this condition it is difficult to determine whether PPWSPs are complying with the 2000 National Water Act of Nigeria and/or the NAFDAC standards specifications, which states that all domestic water supplies should be clean and drinkable. The National Water Act did not mandate any national or state service authority to regulate or monitor PPWSPs and ensure that they supply water of acceptable quality to end-users. Because of this the quality status and health risks associated with using water supplied by PPWSPs is neither known nor documented. Because PPWSPs consider mainly the profit motif in their operations, the approach, if not regulated, can become an instrument for endangering the health of water users.

- Non-provision of incentives to efficient PPWSPs. Another policy-gap is the non-encouragement from governments to efficient PPWSPs to further promote water services delivery. The search for stability in the rural water supply sector in Nigeria has been long and tortuous. Since the enactment of the National Water Reform Act, 2000, government should have found a way of appreciating the new investors who have who have found ways to surmount the challenges which public service provider have battled unsuccessfully for decades. Observed PPWSPs are solely responsible for planning, developing, managing and day-to-day operation of their water infrastructure as well as for setting and collecting water tariff. Maintenance works are contracted out to private companies or to artisans for problems which they cannot fix themselves. Governments do not provide them with technical and other forms of assistance. Since PPWSPs are contributing tremendously to the reduction of water shortages, they deserve assistance and support from governments. Governments can provide them with financial assistance, support for technological upgrading or mandates to protect water sources from contamination since PPWSPs lack authorities for land use restrictions at the local level.

\section{NON-POLICY FACTORS THREATENING THE OPERATIONS OF PPWSPS IN THE SAMPLED COMMUNITIES}

- Poor perception of the quality of water supplied by PPWSPs. Many users have poor perception on the quality of vended water. For instance, only $21 \%$ of the respondents believe that vended water is of good quality, $41.33 \%$ expressed doubts, while $37.67 \%$ condemned the quality in strong terms. Majority of the users expressed deep concerns about the potential health and safety risk posed by vended water. In Abia State, for instance, a respondent noted that PPWSPs lack the capacity to protect users' health by providing safe drinking water: he observed that micro particles such as sand, silt, virus, and colloids have been detected in vended water. In Sokoto State, a public health engineer expressed similar concerns. In Taraba State, an official of the state water board recommended that for vended water to be used for all purposes, elaborate institutional support and strong monitoring systems are necessary.

- Lack of supportive infrastructure/retraining programmes for PPWSPs: The institutional framework for rural water supply in Nigeria, currently, lack well proposed policies on how to strengthen PPWSPs and provide them with supportive, water- related infrastructure, particularly roads and electricity. Inadequate power supply constrains PPWSPs efforts in the generation and distribution of water to rural communities. Apart from not providing PPWSPs with essential infrastructure/ support, findings also show that training and refresher courses are not organized for them or for their support staff (plumbers, borehole managers and administrators).

- Lack of legislations. Although service delivery by PPWSPs has advantages, findings show that there are no legislations on source water protection in Nigeria presently and that the quality of industrial and municipal discharges into streams in Nigeria are not regulated. This may negatively impacts on the quality of surface water from where many PPWSPs abstract their vended water. This finding makes complete dependence on vended water undesirable, particularly in the long term, considering the fact that many concerns were voiced out by users regarding the quality of vended water. The supply of safe drinking water is essential for the protection of users' health; however, the quality of water supplied by PPWSPs is still uncertain.

\section{CONCLUSION AND RECOMMENDATIONS}

In Nigeria, planners and policy makers have, for decades, been concerned with how to improve the efficiency and effectiveness of service delivery in the rural water supply sector [ADELEYE et al. 2014]. The public schemes have generally been unable to deliver on their mandate of providing users with quality and sustainable water services delivery. The poor state of public water services delivery largely account for the emergence of PPWSPs in the water supply sector. The sampled rural population cannot, at present, depend on public water schemes unless significant improvements in the maintenance and rehabilitation of the schemes (which will require long term government interventions) are carried out. Because of this, we have shortterm (actions and measures to be undertaken up to 5 years [ŁABĘDZKI 2016] and long-term (actions and measures to be undertaken in long perspective, up to 25 years [ $\mathrm{EA}$ BĘDZKI 2016] recommendations on how to improve water supply sustainability in the area. In the short term, water sources, supply systems and water infrastructure are relatively fixed; over the long term, however, they can be adjusted, extended, remodeled and/or new sources, supply systems and infrastructures can be developed.

Short-term measures essentially to be taken up at the community level. 


\section{Assistance to PPWSPs}

PPWSPs could be assisted with the under listed forms of support:

- training and capacity building: training and capacity building of PPWSPs, to carry out their roles as effectively as possible may help in improving the quality and sustainability of their services; governments can achieve this by organizing refresher courses for PPWSPs and their staff;

- technical advice: governments should provide technical advice to PPWSPs, on system designs, operation and maintenance activities;

- administrative support: this may include diverse issues such as making the policy environment under which PPWSPs operate to be very accommodating and attractive to high quality, efficiency-seeking private service providers;

- organizational support: this may take the form of assisting PPWSPs in establishing themselves legally; to register their local water schemes, resolve conflicts, obtain an operational license, defining roles and responsibilities, obtain spare parts, loans and sites selection for locating water projects;

- provision of information: governments can facilitate the flow of information across and between PPWSPs and other stakeholders in the water supply sector in order to help them make informed decisions and take appropriate actions to improve the quality and sustainability of water service delivery;

- provision of supportive infrastructure: governments' investments in supportive infrastructural facilities,(roads and electricity) and in the restoration ailing infrastructure may assist PPWSPs in supplying rural households water faster and at lower costs.

\section{Regulation}

Governments should regulate and monitor the operations of PPWSPs in the sampled communities in order to minimize/eliminate the risks involved in entrusting the management of water resources to private entities [ESTACHE, RosSI 2002]. Regulation can be used to reduce extortion, as well as to ensure that the PPWSPs respect their obligations, including developing water supply infrastructure in vulnerable areas. Both the quality of water supplied, source water conditions, tariff structure, system designs etc. could be regulated through:

- use of permits: permits, for instance, can be introduced and used to register and monitor the operations and the quality of water served by PPWSPs;

- bans on sale of contaminated/over-aged water infrastructure: outright bans is probably the strictest form of regulation, and its use in the water supply sector is justified by the desire to safe guard the health and wellbeing of water users; bans can be placed on the use of overaged or decayed water infrastructure, inappropriate production processes/activities around water source areas and on defective specific design.

3. Monitoring and enforcement: A comprehensive monitoring and enforcement system, with appropriate sanctions, will ensure compliance by PPWSPs to the specified standards. Direct as well as indirect monitoring of the quality of water supplied, source water conditions, tariff structure and system designs may assist in ensuring that consumers' interest are protected.

\section{Long-term options}

Within the long-time frame, however, governments can achieve universal access to quality and sustainable water in the sampled communities, through increased investment in water infrastructure, appropriate policies instruments, and by ensuring the sustainability of water infrastructure. The problem of frequent and premature collapse of water infrastructure which is widespread in the region, for instance, can be tackled through effective community participation, provision of spare parts, funds, local resources mobilization; use of quality infrastructure and through special governments'-sponsored rehabilitation initiatives. Specifically, we consider the following strategies necessary.

- Improving the capacity of state water agencies to maintain quality and efficiency in the public water distribution systems.

- Developing a management strategy to address the frequent system breakdowns, maintenance backlog and lack of cost recovery in the public water sector. If the ambitious 2030 Sustainable Development Goals (SDGs) is to be achieved in the Nigeria, then genuine improvements in water service delivery, especially in the longterm is necessary. Improving the quality and sustainability of rural water supply in Nigeria calls for new creative solutions and approaches, including shifts from relying solely on poorly managed and perennially dysfunctional public rural water supply schemes (RWSS) to properly regulated and closely monitored private forprofit water services providers.

\section{REFERENCES}

Abaje I.B., Ati O.F., Ishaya S. 2009. Nature of potable water supply and demand in Jema'a local government area of Kaduna State, Nigeria. Research Journal of Environmental and Earth Science. Vol. 1. Iss. 1 p. 16-21.

ADEKALU K.O., OsUnBITAN J.A., OJO O.E. 2001. Water sources and demand in Ajegunle, Lagos State, Nigeria. Journal of Social Studies. Vol. 1. Iss. 1 p. 1-9.

ADEKAYI P.E. 1991. Harnessing water resources for better life for Nigerians. Nigerian Geographical Association Bulletin. No. 11 p. $7-11$.

Adeleye B., Medayese S., OKelola O. 2014. Problems of water supply and sanitation in Kpakungu Area of Minna, Nigeria. Journal of Culture, Politics and Innovation. Iss. 2 p. 1-9. DOI 10.12893/gjcpi.2014.1-2.9.

Adeoye P.A., AdeOlu A.R., IBRAhim H.M. 2013. Appraisal of rural water supply: Case study of Kwara State, North central Nigeria. International Journal of Basic and Applied Sciences. Vol. 1. Iss. 4 p. 816-826.

AdEROGBA K.A. 2005. Groundwater development in Nigeria: A study of Abeokuta-Ewekoro-Ifo-Ota-Agbara Axis in Ogun State, Nigeria. International Journal of Environmental Issues. Vol. 3. Iss. 1 p. 51-68.

AKPOMUNJE O.B. 2010. Self-help as a strategy for rural development in Nigeria: A bottom-up approach. Journal of Alternative Perspectives in the Social Science. Vol. 2. Iss. 1 p. 88 111. 
AKPOR O.B., MuchIE M. 2011. Challenges in meeting the MDs: The Nigerian drinking water supply and distribution sector. Journal of Environmental Science and Technology. Vol. 4. Iss. 5 p. 480-489. DOI 10.3923/jest.480-489.

ALI K.A. 2012. Development of water supply infrastructure in Nigeria: Challenges and prospects [The 2012 Nigerian Society of Engineers October Lectures]. [04.10.2012 Nsukka].

AMINUK F.T. 2000. Natural resources and land use. In: Environment and sustainable development. Ed. F.T. Aminuk. Ibadan, NCEMA p. 42-49.

AWOPEGBA P.O. 2001. Overview of the planning and management of social services in Nigeria. International Journal of Environmental Science and Technology. Vol. 1 p. 133-140.

Awuah E., Nyarko K.B., Owusu P.A., Osei-Bonsu K. 2009. Small town water quality. Desalination. Vol. 248 p. 453-459.

AyOADE J.O., OYeBANDE B.L. 1983. Water resources. In: Geography of Nigerian development. Eds. J.S. Oguntoyinbo, O.O. Areola, M.O. Filani. Ibadan. Heinemann p. 12-68.

BABIC B., DukiC A., STANIC M. 2014. Managing water pressure for water savings in developing countries. Water SA. Vol. 40. Iss. 2 p. 221-232.

Baguma D., Hashim J.H., AlJunid S.M., LoisKandL W. 2013. Safe-water shortages, gender perspectives, and related challenges in developing countries: The case of Uganda. Science of the Total Environment. Vol. 442 p. 96-102. DOI 10.1016./j.scitotenv.2012.10.004.

Cherlet J., Venot J.P. 2013. Structure and agency: Understanding water policy changes in West Africa. Water Policy. Vol. 15 p. $479-495$.

Chitonge H. 2011. A decade of implementing water services reform in Zambia: Review of outcomes, challenges and opportunities. Water Alternatives. Vol. 4. Iss. 3 p. 1-19.

Estache A., Rossi M. 2002. How different is the efficiency of public and private water companies in Asia? World Bank Economic Review. Vol. 16. Iss. 1 p. 139-148.

EZENWAJI E.E. 2004. Water supply, as a strategy for rural development in Anambra State, Nigeria. Journal Policy and Development Studies. Vol. 1. Iss. 2 p. 71-80.

EZENWAJI E.E., EDUPUTA B.M., OKоYE I.O. 2016. Investigation into the residential water demand and supply in Enugu metropolitan area. American Journal of Water Resources. Vol. 4. Iss. 1 p. $22-29$.

FANIRAN A. 1992. Water resources development in Nigeria. University Lectures. Ibadan. University of Ibadan. ISBN 9781212780 pp. 95.

Ferro G., Lentini E.J., Mercadier A.C., Romero C.A. 2014. Efficiency in Brazil's water and sanitation sector and its relationship with regional provision, property and the independence of operators. Utilities Policy. Vol. 28 p. 42-51. DOI 10.1016/j.jup.2013.12.001.

FMWR 2016. National water resources conservation, action plan: Preliminary report. Vol. 1. Abuja. Federal Ministry of Water Resources and Rural Development, Federal Republic of Nigeria p. $15-16$.

Fotso J., Ezeh A C., MAdise N.J., Ciera J. 2007. Progress towards the child mortality millennium development goal in urban sub-Saharan Africa: The dynamics of population growth, immunization, and access to clean water. BMC Public Health. Vol. 7 p. 218. DOI 10.1186/1471-2458-7-218.

GBADEGESIN N., OLORUNDEMI F. 2007. Assessment of rural water supply management in selected rural areas of Oyo State, Nigeria. ATPS Working Paper Series. No. 49. African Technology Policy Studies Network (ATPS), Nairobi, Kenya. ISBN 9966-916-12-1 pp. 55.

HusSMANNS R. 2004. Measuring the informal economy: From employment in the informal sector to informal employment.
Working Paper. No. 53. Geneva. ILO Integration. ISBN 92-2116985-5 pp. 32.

LO STORTO C. 2013. Are public-private partnerships a source of greater efficiency in water supply? Results of a nonparametric performance analysis relating to the Italian industry. Water. Vol. 5. Iss. 4 p. 2058-2079. DOI 10.3390/ w5042058.

LONGE E.O., ENEKWECHI L.O. 2007. Investigation on potential groundwater impacts local government case study, Lagos State, Nigeria. Journal of Engineering Research. Vol. 14. Iss. 4 p. $1-12$.

LONGE E.O., UKPEBOR E.F., OMOLE D.O. 2009. Household waste collection and disposal in Ojo local government case study, Lagos State, Nigeria. Journal of Social Sciences. Vol. 4. Iss. 2 p. 1-12.

ŁABĘDZKI L. 2016. Actions and measures for mitigation drought and water scarcity in agriculture. Journal of Water and Land Development. No. 29 p. 3-10. DOI 10.1515/jwld-2016-0007.

Majuru B., Mokoena M., Jagals P., HunTer P.R. 2011. Health impact of small community water supply reliability. International Journal of Hygiene and Environmental Health. Vol. 214. Iss. 2 p. 162-166.

Metwally A.M., IBRAhim N.A., SAAD A., ABU El-Ela M.H. 2006. Improving the roles of rural women in health and environmental issues. International Journal of Hygiene and Environmental Health. Vol. 16. Iss. 2 p. 133-144.

NPC 2006. Population census of the Federal Republic of Nigeria. Analytical report at the national level. Abuja, Nigeria. National Population Commission p. 4-7.

NwANKOALA H.O. 2011. The role of communities in improved rural water supply systems in Nigeria: Management model and its implications for vision 20:2020. Journal of Applied Technology in Environmental Sanitation. Vol. 1. Iss. 3 p. 295-302.

NZEADIBE T.C., AJAERO C.K. 2010. Solid waste governance innovations: an appraisal of recent developments in the informal sector niche in urban Nigeria. Geography Compass. Vol. 4. Iss. 9 p. 1284-1296. DOI 1111/j.1749-8198.2010.00385.x.

OFOEZIE I.E. 2003. Environmental assessment of water resources for development programmes in Nigeria. In: Techniques in environmental studies. Ed. H. Jimoh. Ilorin, Nigeria. Nathadex Publishers p. 23-31.

OKeJE E.O., UdOh E.J., ETIM L. 1989. Nigeria development of water resources: Towards the achievement of the international drinking water supply and sanitation decade. WWC Bulletin. No. 9 p. $18-25$.

OKonkwo J.N., OKorie O., OKonkwo C.J.O. 2011. Public health risk status of the water supply framework at Kwame Nkrumah. African Journal of Environmental Science and Technology. Vol. 5. Iss. 1 p. 522-529.

OlALEYE Y.L. 2010. The contributions of the doctrine of citizens' participation in organization and implementation of community development project. European Journal of Science Research. Vol. 6. Iss. 5 p. 113-126.

OMOLE D.O. 2015. Sustainable groundwater exploitation in Nigeria. Journal of Water Resources and Ocean Science. Vol. 2. Iss. 2 p. $9-14$.

OMOLE D.O., ISIORHO S. 2015. Waste management and water quality issues in coastal states of Nigeria. Journal of Sustainable Development in Africa. Vol. 13 (6) p. 207-217.

Omole D.O., Ndambuki J.M., Balogun K.O. 2015. Consumption of sachet water in Nigeria: Quality, public health and economic perspective. African Journal of Science and Technology, Innovation and Development. Vol. 7. Iss. 1 p. 45-45.

OYEGUN R.O. 2001. Environmental problems and water resources development: A geographical perspective. In: Geographical perspectives on environmental problems and management in 
Nigeria. Eds. G.E.K. Ofomata, P.O. Phil-Eze. Enugu, Nigeria. Jamoe Enterprises p. 236-257.

Pavelic P., Giordano M., Keraita B., Ramesh V., Rao T. (eds.) 2012. Groundwater availability and use in Sub-Saharan Africa: A review of 15 countries. Colombo, Sri Lanka: International Water Management Institute (IWMI). ISBN 978-929090-758-9 pp. 274.

RAKODI C. 2000. Getting the pipe laid is one matter and getting the water flowing through the pipe is another user views on public-sector urban water provision in Zimbabwe, Sri Lanka, Ghana and India. International of Planning Studies. Vol. 5. Iss. 3 p. 365-391. DOI 10.1080/713672857.

SALETH R.M., DiNAR A. 2004. The institutional economics of water: A cross country analysis of institutions and performances. Cheltenhem. U.K. Edward Elgar, Publishing House, U.K. ISBN 0-8213-5656-9 pp. 416.

Satterthwaite D. 2016. Missing the millennium development goal targets for water and sanitation in urban areas. Environment and Urbanization. Vol. 28. Iss. 1 p. 99-118.

Smits S., Verhoeven J., Moriarty P., Fonseca C., Lockwood H. 2011. Arrangements and costs of support to rural water service providers. WASH Working Paper. No. 5. The Hague, the Netherlands: IRC International Water and Sanitation Centre pp. 43.

Uluocha N.O. 2005. Weather, climate, water and sustainable development in Nigeria. [World Metrological Day Celebration, at the Meteorological Research and training Institute]. [Oshodi, Lagos, 23.03.2005].

WAZIRI M. 2009.The geography of Bornu State, Nigeria: An overview. In: Issues in geography of Bornu State, Nigeria. Eds. M. Waziri, A. Kagu. Maiduguri. University of Maiduguri Press p. 6-8.

WHO and UNICEF 2012. Progress on drinking water and sanitation 2012 Update. WHO/UNICEF Joint Monitoring Programme (JMP) for water Supply and Sanitation. Geneva. World Health Organization. ISBN 978-92-4-150329-7 pp. 59.

WHO and UNICEF 2015. Progress on sanitation and drinking water: Update WHO/UNICEF (JMP) for water Supply and Sanitation and MDG Assessment. Geneva. World Health Organization. ISBN 978-924-150724-0 pp. 80.

\section{Michael Chukwuma OBETA}

\section{Prywatne, komercyjne zaopatrzenie w wodę w Nigerii: ograniczenia polityczne i możliwości lepszego funkcjonowania}

\section{STRESZCZENIE}

Niedostatek wody jest głównym i narastającym problemem na wiejskich obszarach Nigerii, przyczyniając się do powstawania prywatnych, komercyjnych dostawców wody (PPWSPs). W niniejszej pracy scharakteryzowano usytuowanie prywatnych dostawców w wiejskich społecznościach Nigerii na podstawie informacji zdobytych w obserwacjach terenowych, wywiadach, ankietach i pochodzących z literatury tematu. Zgromadzone dane analizowano za pomocą opisowych narzędzi statystycznych. Wyniki ujawniły charakterystyki, kategorie, udział i obawy odbiorców wody co do dostaw realizowanych przez dostawców. Odpowiedzi świadczą, że firmy te wspierają rozwój, gwarantują odbiorcom wystarczający i niezawodny dostęp do zasobów wody i zmniejszają ograniczenia w tym dostępie wśród badanych społeczności. Zapotrzebowanie na wodę jest zaspokajane przez PPWSPs w 64\% analizowanych gospodarstw domowych. Wiele takich firm działa poza zakresem rządowych regulacji i realizuje zróżnicowane sposoby dostarczania usług i ustalania cen, aby osiągnąć szerszą akceptację. Mimo postępu dokonanego przez PPWSPs, taka strategia nie gwarantuje powszechnego dostępu do wody ani dostaw bezpiecznej wody pitnej. W pracy przedyskutowano znaczące ograniczenia w działaniach dostawców wody, sposoby wypełnienia luk prawnych, które ograniczają usługi świadczone przez te firmy, oraz sposoby ulepszenia ich funkcjonowania poprzez ustanowienie standardów i regulacji prawnych.

Słowa kluczowe: możliwości poprawy funkcjonowania, Nigeria, ograniczenia polityczne, prywatne dostawy wody, publiczne systemy wodne, społeczności wiejskie 